\title{
Cartesian Auto Body
}

LAWRENCE RHU

“Son of man, can these bones live?” Ez 37:3

I.

"The body and the engine are one," declares

Dnezivich, the Senior Specialist

In Total Loss. "They're indivisible,

A single unit." Naturally, he prevails

Though nature plays no part in his discourse.

I haven't heard so much philosophy

In years; it promptly silences appeals

To values dutifully applied in practice:

Required maintenance performed, as scheduled,

Every three months or three thousand miles.

"Please, don't bother with that bump or scratch,"

I say to Frank at Suddeth Automotive.

"We need this van for work and family trips,

Not for parades, although we love parades."

A visitor once peeked beneath the hood 
And raved spontaneously in praise of what,

To his surprise, he saw and heard inside:

The clear efficient hum of finely tuned

Well-oiled parts, each performing its own role,

Thanks to Frank, Amy, Mike, and John at Suddeth.

Could partial loss and total be the same?

II.

Seated by the fire in contemplation,

Descartes resolved his fierce and vexing doubts.

How could he not exist if he was doubting

His own existence? If he did not exist, Who was doing the doubting? As for you

And me or others he might see pass by

In overcoats and hats outside his window, How could he know we were not automata, Wearing hats and coats, of course, but still,

Who could say for sure we were, like him, just folks In heavy clothes hustling down chilly streets?

This dilemma did not lead Descartes to God.

Although he got there other ways, he left

Us in the cold-automotons in hats

And coats. Some things you never know for sure- 
The authorship of Shakespeare's plays, the birthPlace of Obama. What makes me think I know I landed on the shores of light

In West Penn Hospital? Vertigos of doubt Can make heads spin, and quests for absolutes Are bound to fail. With standards high as those,

Descartes himself could not succeed. We know Foreseeably for sure that water boils At sea level at $212^{\circ}$,

But we know we exist from inside out, Subjectively. Consider Hecht's “A Letter,” "I have been wondering what you are thinking about

"And by now suppose, it is certainly not me." Supposition here morphs into certainty Only if we trust the speaker. The unnamed Addressee alone and only to herself Could verify this loner's abject claim. Acknowledgement must own what can't be proved.

III.

But I'm in pain and you can recognize My pain. My humanity and yours become Discernible through agons such as these, 
However minor. I'm no stoic hero

Nor am I a self-indulgent whiner.

I'll playfully recover from my loss,

Absorb the shock, laugh off the arbitrary

Damage at my insurance agency's

Expense of spirit. But, please, give me a moment.

Salvage yards keep calling me-four times

Yesterday, three times today. My loss,

They've heard, is total, but their interest

In my wiped out car belies that drastic claim,

Making me wonder, What is in this deal

For everybody else but me? Why strive

For what's worth less than its repair will cost?

A chop shop lady dunned me pleasantly,

As though the vulture read Miss Manners.

Dnezivich recited his monadic premise

Regally, but somehow I forgot his words

Are only registers of market value.

Shall I go mad with undue empathy

Considering such conversations soul-

To-soul? Please, don't let me forget again.

IV.

In this regard my patience has a limit.

My driver's license designates that I'm

An organ donor. Mortality's enough 
To make me glad to share with those in line

And need of this or that-an eye or hand,

A lung or liver-spare parts, which become

Useless to yours truly after my last breath.

Meanwhile, if it's utility, not love,

That brings you near, please, keep away from me

And from our minivan. Integrity's

A task that I've been working on for decades

Now, with mixed results but no surrender.

Although I set no such high standards

For our aging storied family Odyssey,

No rival theorist of value, no Senior

Specialist in Total Loss may stake

A claim on any part of me or our

Beloved Honda's body glorified. 